\title{
Ethical problems experienced by nurses in primary health care: integrative literature review
}

\author{
Problemas éticos vivenciados por enfermeiros na \\ atenção primária à saúde: revisão integrativa da literatura \\ Problemas éticos experimentado por enfermeros en la \\ atención primaria de salud: revisión integrativa de la literatura
}

\author{
Carlise Rigon Dalla Nora ${ }^{a}$ \\ Elma Lourdes Campos Pavone Zoboli ${ }^{\text {b }}$ \\ Margarida Vieirac
}

\begin{abstract}
The aim of this study is to identify ethical problems experienced by nurses in primary health care and resources for coping based on publications on the subject. An integrative literature review was performed between the months of October and November 2013, using the databases: BDTD, CINAHL, LILACS, MEDLINE, Biblioteca Cochrane, PubMed, RCAAP and SciELO. Articles, dissertations and theses published in Portuguese, English and Spanish were included, totalling 31 studies published from 1992 to 2013. This analysis resulted in four categories: ethical problems in the relationship between team members, ethical problems in the relationship with the user, ethical problems in health services management and resources for coping with ethical problems. Results showed that nurses need to be prepared to face ethical problems, emphasizing the importance of ethics education during the education process before and during professional practice to enhance the development of ethical sensitivity and competence for problem resolution.
\end{abstract}

Keywords: Ethics. Ethics nursing. Primary health care. Nursing. Review.

\section{RESUMO}

Este estudo tem como objetivo identificar problemas éticos evidenciados por enfermeiros da atenção primária e recursos de enfrentamento a partir de publicações sobre a temática. Realizou-se uma revisão integrativa da literatura entre os meses de outubro e novembro de 2013, nas bases: BDTD, CINAHL, LILACS, MEDLINE, Biblioteca Cochrane, PubMed, RCAAP e SciELO. Foram incluídos artigos, dissertações e teses publicados em inglês, espanhol e português, no período de 1992 a 2013, totalizando 31 estudos. Da análise resultaram quatro categorias: problemas éticos na relação entre a equipe, problemas éticos na relação com o usuário, problemas éticos na gestão dos serviços de saúde e os recursos de enfrentamento dos problemas éticos. Conclui-se que os enfermeiros precisam ser preparados para enfrentar os problemas éticos, evidenciando-se a importância da formação em ética durante o processo educativo, antes e durante a prática profissional, proporcionando o desenvolvimento de sensibilidade e competência ética para a resolução desses problemas.

Palavras-chave: Ética. Ética em enfermagem. Atenção primária à saúde. Enfermagem. Revisão.

\section{RESUMEN}

Este estudio tiene como objetivo identificar los problemas éticos experimentado por las enfermeras en la atención primaria y los recursos de afrontamiento de las publicaciones sobre el tema. Se realizó una revisión integradora de literatura, entre los meses de octubre y noviembre de 2013, en las bases de datos: BDTD, CINAHL, LILACS, MEDLINE, Biblioteca Cochrane, PubMed, RCAAP y SciELO. Se incluyeron artículos, disertaciones y tesis publicadas en inglés, español y portugués, en un total de 31 estudios, en el período de 1992 a 2013. El análisis resultó en cuatro categorías: problemas éticos en la relación entre el equipo, problemas éticos en la relación con el usuario, problemas éticos en la gestión de los servicios de salud y los recursos de afrontamiento de los problemas éticos. Se concluye que los enfermeros han de estar preparados para hacer frente a los problemas éticos, destacando la importancia de la formación ética durante el proceso de la educación antes y durante la práctica profesional, lo que permite el desarrollo de la sensibilidad ética y competencias éticas para la resolución de estos problemas.

Palabras clave: Ética. Ética en enfermería. Atención primaria de salud.Enfermería. Revisión.
D0l: http://dx.doi.org/10.1590/1983-

1447.2015.01.48809 


\section{DINTRODUCTION}

Primary health care (PHC) has been defined as a set of principles and values that help guide health care systems $s^{(1)}$, representing the port of entry to these systems and enabling communication between the community and health care services ${ }^{(2)}$.

PHC, as in all other scopes of health care systems, prompts the emergence of ethical issues related to service organization and work processes ${ }^{(3)}$. In their daily practice, PHC professionals experience a wide range of complex and significant ethical problems, although several of these problems are not acknowledged as being ethical in nature ${ }^{(4)}$.

Ethical problems related to health care are defined as being ethical aspects, issues or implications, common or not, in health care practices ${ }^{(5)}$. Ethical problems cannot be considered situations in which the solutions are restricted to extreme and opposite outcomes, which is typical of ethical dilemmas ${ }^{(6)}$. Ethical problems are challenges, sources of conflict of values and duties that have several courses of action leading to a solution, and require deliberation and reflection to find the best path, which must be continually re-assessed. Ethical problems cannot be solved with ready-made recipes, but rather demand permanent creativity to open a possible array of solutions to achieve ethical excellence in health care practices.

Studies on ethical problems in health care have mostly been conducted in the hospital environment, with discussion and reflection surrounding "borderline situations" which usually include topics such as euthanasia, abortion, assisted reproduction and cloning ${ }^{(7)}$. However, to improve health care, professionals must be aware of the ethical problems that arise in $\mathrm{PHC}^{(3)}$. Consequently, there is a need for research that enables the discussion of ethical issues in $\mathrm{PHC}^{(3,5)}$.

The type of ethical problems faced by nurses may vary according to their practice environment. In the hospital environment, there are dramatic scenes; critical life-or-death situations that receive media coverage and require immediate solutions. Ethical issues in PHC tend to be more subtle. As they are considered common in daily PHC practices, they become more difficult to identify, which increases their complexity ${ }^{(3,8-9)}$. Primary care nursing, compared with hospital practice, allows greater autonomy ${ }^{(9)}$, which can also influence the configuration of ethical problems experienced by PHC nurses ${ }^{(3)}$. Consequently, the guiding questions of this study were: what are the ethical problems experienced by nurses in primary health care? What are the proposed resources to cope with these ethical problems?

Failure to perceive ethical problems experienced by PHC nurses may compromise the quality of the provided health services by imposing a risk of rupturing the bond between professionals and users ${ }^{(10)}$. Based on these considerations, the aim of this study was to identity ethical problems experienced by nurses in primary health care and the resources to cope with these problems based on literature on this topic.

\section{METHOD}

The integrative review method was adopted for this study ${ }^{(11)}$. This is the most comprehensive research review method because it allows a broader understanding of a given topic and pinpoints knowledge gaps that should be explored by conducting new studies. To ensure accuracy of the integrative review, research was based on the stages of problem identification, bibliographical research, data analysis and presentation ${ }^{(11)}$.

The guiding questions of this study were: What are the ethical problems experienced by nurses in primary health care? What are the proposed resources to cope with these ethical problems? To answer these questions, bibliographic research was conducted in the following online databases and libraries: BDTD - Biblioteca Digital Brasileira de Teses e Dissertações, CINAHL- Cumulative Index to Nursing and Allied Health Literature, LILACS Literatura Latino-Americana e do Caribe em Ciências da Saúde, MEDLINE- Medical Literature Analysis and Retrieval System Online, Cochrane Library, PubMed, RCAAP Repositório Científico de Acesso Aberto de Portugal and SciELO - Scientific Electronic Library Online.

The adopted descriptors/MeSH and key words were: ethics, nursing ethics, bioethics, ethical dilemma, ethical challenges, primary health care, health services, primary nursing, primary care nursing, nurse's role, family health program, public health. These descriptors were used in English, Portuguese and Spanish. Boolean operators were used to make the following associations: ethics and primary health care, ethical dilemma and nursing ethics, ethical challenges or ethical dilemma, ethical challenges and bioethics, ethical challenges and primary care nursing, ethical dilemma and family health program. The references from selected articles were used to conduct a reverse search, that is, one of the search strategies was also the reference of the reference. 
Inclusion criteria were: articles from original research and reports of experiences, dissertations and theses published in English. Spanish and Portuguese, on nurses who referred to ethical problems in primary health care. No criteria were established in relation to time limits.

Exclusion criteria were: studies conducted in the hospital environment; users as research subjects; studies with a research design or objectives that were not clearly defined or explained; editorials, journalistic articles, of conjunctural analysis, protocol assessment, theoretical concept discussion, non-original articles (such as reviews or comments) and secondary studies, such as bibliographical reviews.

The theses and dissertations were included to expand the search parameter and map all production on the topic, as some studies are not published in indexed journals, that is, they remain in the university repositories. Searches of theses and dissertations were conducted in Brazilian and Portuguese databases considering the similarities of the health care systems in these countries, where ethical problems experienced by nurses may also be similar. This study is the result of research conducted by the authors during doctoral degree studies in nursing at the Universidade Católica Portuguesa.

Data were collected and analysed between October and November 2013, separately, by two researchers. Results were compared and inconsistencies were resolved by consensus. PRISMA ${ }^{d}$ recommendations, represented in figure 1, were used to select the publications included in this study.

Data were analysed and interpreted using systematic literature review procedures ${ }^{(11)}$ with problem identification, bibliographical research, data evaluation, data analysis and presentation. The initial stage consisted of identifying the problems or study guiding questions. Secondly, databases for the searches were defined. In the data assessment stage, the quality of evidence was verified. Data were then analysed, ordered and categorized with a structured instrument, where study information was recorded, based on the guiding questions. Finally, the results were presented by joining all the important elements into an integrative summation of the topic.

\section{DESULTS}

A total of 1545 publication on the subject were identified, of which 31 were selected to integrate the sample. Of these 31 publications, 25 were articles ${ }^{(3,4,7-10,12-30)}$, five were dissertations ${ }^{(31-35)}$ and one was a thesis ${ }^{(36)}$. Figure 1 is a flowchart of the studies inclusion process.

The journal with the highest number of studies (twelve) was Nursing Ethics (impact factor 1.210, evaluation year 2012); the Journal of the American Association of Nurse Practitioners (impact factor 0.709, evaluation year 2012) resulted in two studies. The journal with the best impact factor was The Journal of Epidemiology and Community Health, with one study (impact factor 3.192, evaluation year 2012). Considering a classification with 7 evidence quality levels (37), the results of this integrative review are level 6 evidence, as they are from a single descriptive or qualitative study.

Four studies from Portuguese universities ${ }^{(32-33,35-36)}$ and two from Brazilian universities ${ }^{(31,34)}$ were included. In terms of language of the published studies, eighteen were in English $^{(4,8,9,12,14-16,19-20,22-30)}$, twelve in Portuguese ${ }^{(3,7,10,17-18,21,31-36)}$ and one was in Spanish ${ }^{(13)}$.

Studies included in the sample were mostly published after the year 2000, and only two articles were published in the 1990 s $^{(12,14)}$.

Most studies were published in the United States (Maryland $^{(22,28-29)}$, Minnesota ${ }^{(15)}$, Idaho ${ }^{(16)}$ and Chicago ${ }^{(8)}$, others ${ }^{(9,24,26)}$ ) and in Brazil (São Paulo ${ }^{(3,7,10,13,18,21,34)}$, Paraná(31) and Rio Grande do Sul $\left.{ }^{(17)}\right)$.

In relation to nature of the studies, nineteen were qualitative (2,7-8,12-15,17-20,22-26,30-31,36), eight were quantitative $e^{(9-10,27-29,32,34-35)}$ and four were quail-quantitative ${ }^{(4,16,21,33)}$. For data collection, the most widely adopted methods were questionnaire ${ }^{(9-10,12,16,18,22,24-29,32-35)}$, interviews ${ }^{(3,7-8,13-14,20-}$ $21,23,30,36)$, focal group ${ }^{(15,17,31)}$ and combination of focal group and questionnaire ${ }^{(4,19)}$.

The predominant analysis methodology mentioned in the studies was content analysis $(3,7,12,15,19,22-26,31,36)$, followed by statistical analysis (9-10,27-29,32-35), hermeneutic analysis $(13,17,30)$, deliberation ${ }^{(18)}$, thematic analysis ${ }^{(20)}$, grounded theory ${ }^{(8,14)}$ and a combination of methods, such as content analysis and statistical analysis ${ }^{(4,16,21)}$.

In relation to the authors, thirteen were university professors ${ }^{(4,8,12,14-16,20,22-25,27,30)}$, nine had a post-doctorate degree $(3,7,13,17-19,26,28-29)$, three were masters of nursing ${ }^{(10,33-34)}$, two were masters of bioethics ${ }^{(32,35)}$, one had a PhD in nursing (36), one was a doctoral degree student (9), one was a master of education ${ }^{(31)}$ and one was a nursing student ${ }^{(21)}$.

${ }^{d}$ Moher D, Liberati A, Tetzlaff J, Altman DG, The PRISMA Group (2009). Preferred Reporting Items for Systematic Reviews and Meta-Analyses: The PRISMA Statement. PLoS Med 6(6): e1000097. doi:10.1371/journal.pmed1000097. For more information, visit: www.prisma-statement.org 


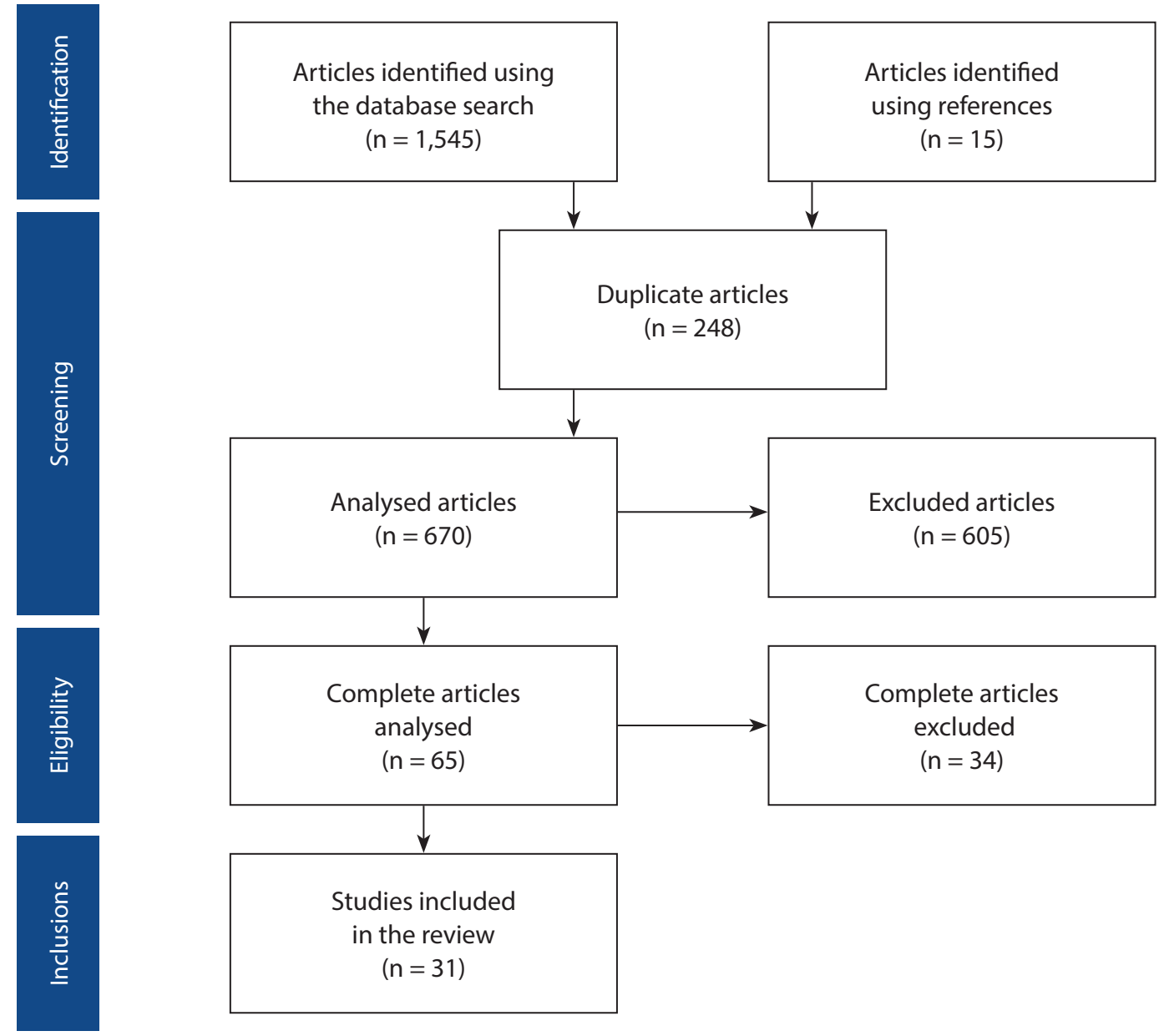

Figure 1. Flowchart of the studies selection process for an integrative literature review.

Analysis led to three ethical problem categories: ethical problems in the relationship between team members, ethical problems in the relationship with the user, and ethical problems in relation to health services management. Resource for coping with ethical problems was the fourth empirical review category.

\section{Ethical problems in the relationship between team members}

This category describes problems identified in the relationship between team members, including issues related to the work process, inter-professional relationships, information and education of nurses who experience ethical problems (Chart 1).

The factor that most generates ethical issues in the nurses' work process was the significant care demand ${ }^{(9-}$ 10,17,33-34). In terms of professionals relationships, the most common problem was disrespect among team members $(3,9-10,13,33-34)$, which reveals a disregard for the specific knowledge and experience of nurses ${ }^{(22)}$.

PHC combines the services of several professionals from different practice areas, with distinctive skills and practices, that must assume the commitment of working in a team and provide comprehensive quality care amidst relationships at different hierarchical levels ${ }^{(21)}$.

Recurring results in the studies were ethical problems related to private information ${ }^{(26,36)}$ and potential threats to privacy and the confidentiality of information ${ }^{(3,12,20,23,25)}$.

In terms of professional education, one study (23) revealed that nurses receive little ethical training during their initial education and a small group managed to identify formal opportunities to discuss ethics at their work place. Other studies ${ }^{(10,13,15,33-34)}$ indicated situations in which nurses were unprepared to work in PHC, although another study revealed that professionals did not have the appro- 


\begin{tabular}{|c|c|}
\hline Sub-categories & Identified ethical problems \\
\hline Work process & $\begin{array}{l}\text { Care demand }{ }^{(9-10,17,33-34)} \\
\text { Completion of tasks/goals }{ }^{(23,30)} \\
\text { Time distribution }{ }^{(20)} \\
\text { Technical procedures }^{(15)}\end{array}$ \\
\hline Inter-professional relationships & $\begin{array}{l}\text { Disrespect among team members }(3,9-10,13,33-34) \\
\text { Lack of commitment within the team }{ }^{(3,10,13,23,34)}\end{array}$ \\
\hline Information & $\begin{array}{l}\text { Privacy and confidentiality }(3,12,20,23,25) \\
\text { Transmitting information to users }(9,20,26,36) \\
\text { Secrecy }^{(26,36)}\end{array}$ \\
\hline Education & Lack of preparation to work in primary health care $(10,13,15,33-34)$ \\
\hline
\end{tabular}

Chart 1. Ethical problems in relation to team members

Source: Research data, 2013.

\section{Sub-category}

\begin{tabular}{|l|l|}
\hline \multirow{2}{*}{ Communication } & $\begin{array}{l}\text { Information to patients }(3,4,7,10,12,13,26,33,34,36) \\
\text { Privacy }(7,10,14,25,26,33,34) \\
\text { Confidentiality }{ }^{(3,20,23,26)}\end{array}$ \\
\hline Autonomy & Respecting the user's autonomy $(7,13,14,20,28)$ \\
\hline Respect & Lack of respect of nurses in relation to users $(7,10,13,21,33,34)$ \\
\hline
\end{tabular}

Chart 2. Ethical problems in relation to users

Source: Research data, 2013.

priate profile ${ }^{(17)}$. The study ${ }^{(24)}$ showed that nurses feel moderately or very prepared to cope with ethical challenges in the nursing practice.

Ethical problems in care practices are a source of stress for nurses in $\mathrm{PHC}{ }^{(20)}$, frequently subjecting professionals to moral suffering $(9,15-16,22,24)$.

\section{Ethical problems in the relationship with users}

This category comprises ethical problems experienced by nurses in relation to users, including communication with patients, autonomy and respect between nurses and users (Chart 2).

The most distinct ethical problems in the studies were related to communication, especially in terms of providing information to patients $(3,4,7,10,13,26,36)$. The reported prob- lems were associated to omitted information ${ }^{(33-34)}$, inadequate information (12) and leaking of personal information of users ${ }^{(25)}$.

A study ${ }^{(26)}$ reported that loopholes in confidentiality and privacy may occur due to the recklessness of nurses, for example: when speaking on the phone; leaving user files open in unattended computers, or talking about private issues in public spaces. Protecting the privacy of users is perceived as an ethical problem by nurses, as they have access to private information of patients and their family members ${ }^{(7,10,14,33-34)}$.

Patient autonomy is a fundamental element of the nurse-user relationship and was one of the most widely stated when discussing ethical problems ${ }^{(7,13,14,20,28)}$. An ethical problem that was commonly found in the studies was based on the refusal of patients to follow orien- 
Sub-category

Identified ethical problems

\begin{tabular}{|l|l|}
\hline Human resources & Lack of time of nurses to meet all the needs of users $(8,9,15,16,23,30)$ \\
\hline Financial resources & Lack of financial resources $(15,25,27,33,34)$ \\
\hline Physical resources & Lack of physical structure $(3,10,21,33,34)$ \\
\hline External influences & Conflict between political decisions and user interests ${ }^{(17,23)}$ \\
\hline
\end{tabular}

Chart 3. Ethical problems in relation to health services management

Source: Research data, 2013.

tations of health care professionals ${ }^{(3,10,14,33-34)}$ and of not accepting the service offered, when these professionals believed it to be the best for them ${ }^{(19)}$. Lack of respect of nurses in relation to users also appeared as an ethical problem ${ }^{(7,10,13,21,33-34)}$

\section{Ethical problems in relation to health services management}

This category shows the problems related to health services management. Findings refer to human, physical and financial resources and external influences (Chart 3).

Of the problems related to organization of the health care system, the most widely reported was the nurses' lack of time to meet all the needs of patients $(8-9,15-16,23,30)$ and difficulties in the reference and counter-reference system ${ }^{(3,10,33-34)}$. Studies ${ }^{(15,27)}$ indicated that the low number of employees and constant switching between team members ${ }^{(17)}$ generated ethical problems due to the provision of care that failed to fully meet the needs of users ${ }^{(4)}$.

In terms of lack of financial resources, a study ${ }^{(15)}$ revealed conflicts between the financial interests of the institution (cost containment) and the needs of patients (equipment and special medication).

The lack of physical structure in these services was also identified as a factor that generated ethical problems $(3,10,21,33-34)$. The nurses stated difficulties in preserving the privacy of users due to problems with the structure and routine in health care units ${ }^{(10)}$. They also reported lack of structural support to discuss and solve ethical problems in the health services ${ }^{(10,21)}$.

Political decision-makers were also considered the causers of ethical problems ${ }^{(17,23)}$. A study ${ }^{(23)}$ identified that some members of parliament used their influence to facilitate care to patients that are dissatisfied with the health system, although they could bring benefits to these services by attracting publicity and resources to low priority demands. In one way or another, the interference of local politicians on the workings of health services seeks to benefit their political clientele ${ }^{(17)}$.

\section{Resources for coping with ethical problems}

The resources for coping with ethical problems that were most widely mentioned in the publications were training and education (3,10,21,33-34). Undergraduate students in nursing ${ }^{(32)}$ considered that the subject of ethics made them better people and that ethics education should be included in all course years. Education should warn students on ethical problems and train them to cope with the challenges in the different practice contexts ${ }^{(18,29,36)}$. One study ${ }^{(18)}$ indicated that the model of deliberation based on problematization helps to solve ethical problems.

Nurses need support to cope with ethical problems, which reveals the need to expand ethical knowledge and discussions ${ }^{(4,12,23)}$, and address clinical experiences, counselling and strategies to manage ethical conflicts ${ }^{(24)}$. Nurses must be encouraged to develop ethical skills to systematically cope with ethical problems ${ }^{(4)}$ and the competencies to permanently listen and talk to users ${ }^{(33)}$.

Support policies included: the presence of a supervisor, colleague or expert professional that can provide advice, and the possibility of consulting an ethics committee ${ }^{(12,14,24) \text {. }}$

\section{DISCUSSION}

Findings of this review revealed that ethical problems in primary health care are caused by routine concerns in health care services. This can explain why ethical problems in PHC are subtle and difficult to recognize as such by the 
professionals ${ }^{(5)}$. To establish, at these services, continued ethics education initiatives may create awareness on ethical problems, lead to the development of ethical competencies and prompt the search for support in ethics committees for conflict resolution ${ }^{(4)}$.

The fact that professionals are unprepared to practice in PHC was mentioned in a study ${ }^{(10,13,15,33-34)}$. The most frequent ethical problems are the result of conflict in relationships with other professionals, and the most disturbing issue is dealing with incompetent colleagues, which prevents nurses from performing their work in ideal conditions, thus generating discomfort and anguish ${ }^{(38)}$.

With respect to the absence of a professional profile to work in PHC revealed in the review, which could be caused by an education that is more centred on the biomedical model with a fragmented outlook on the health-sickness process ${ }^{(17)}$, there is a growing number of professionals with more sensitive profiles that perceive the real needs of the population and produce care that can decisively lead to social satisfaction and technical excellence for users.

Moral suffering is when an individual with a moral responsibility is faced with obstacles that prevent the performance of a desired action, resulting in negative feelings of impotence, psychological pain or imbalances ${ }^{(39)}$. The resulting anguish affects the health team and reinforces the perception of ethical issues as stressors of routine practices by all the health care professionals.

In the review, the most relevant ethical problems related to the relationship with users were information, confidentiality, privacy and autonomy $(3,12,20,23,25)$. The most frequent ethical issues for nurses are related to the desire, which is not always effective, of protecting the rights of patients and human dignity, and of respecting the informed consent of patients.

The relationship between nurses and users requires respect to protect the intimacy and identity of patients, thus creating an ethical relationship that enables professional autonomy and promotes dignity when providing primary care ${ }^{(39)}$. Health professionals must provide individualized care that is based on mutual respect, interaction, and the incorporation and creation of appropriate environments to build an unrestrained and harmonious ethical relationship.

The nurses identified several barriers to the practice of "good nursing", such as disrespect toward patients, especially in relation to delays caused by excessive demand $(9-10,17,33-34)$. The disrespectful attitude of team members to- ward patients was reported in different studies $(7,10,13,21,33-34)$ as being the generator of ethical problems.

PHC is characterized by forming a bond and establishing the responsibility of teams and users ${ }^{(2)}$, being that this proximity favours trust between providers and patients, and allows these users to manifest any objections, fears and concerns. The role of nurses is to be available to talk and explain the consequences of any course of action chosen by users. Ethical problems experienced in this context are marked by the unpredictability of results that is inherent to human reactions within the scope of health, which tends to be greater in primary care due to the peculiarities of these relationships ${ }^{(10)}$.

Most ethical conflicts in the professional-user relationship are the result of misunderstandings and faulty communication, especially the absence, failure to understand or inaccuracy of information provided to users ${ }^{(12)}$. Consequently, good communication between nurses and users can reduce the emergence of ethical issues in PHC and favour the satisfactory development of a therapeutic and ethical relationship.

Humanized health care must ensure the right to information, one of the key elements for user to make substantially autonomous decisions on their health. A relationship based on trust, bonds and joint responsibilities is essential for nurses to respect the user's autonomy, convey information that is easy to understand in a simple, respectful manner, and subsequently increase the likelihood of adherence to treatment.

Ethical problems related to health services management include decisions on defining priority services, as it is not possible to meet all the deadlines and organizational conditions with such significant care demands ${ }^{\left({ }^{30}\right)}$. Nurses are forced to choose priorities by rationalizing the situation, as they cannot perform all the tasks they would like to perform. Nurses are responsible for their actions and for the decisions they make.

The lack of human resources, stated as an ethical problem of PHS in the review, may compromise the quality of care. Studies that support this finding ${ }^{(15,27)}$ report the frequency of ethical issues related to staff shortages and limiting user access to nursing care.

The lack of financial and human resources was considered an impediment to the transition from care-oriented practices to user-oriented practices, and was thus mentioned as being a source of ethical problems $(15,25,27,33)$. The lack of financial resources was also considered a barrier to the development of good professional practices $(15,25,27,33)$. 
Acknowledging resources for coping with ethically problematic situations that are used or valued by nurses can help solve ethical problems that appear in the daily routines of health services by means of continued education and monitoring professional practice and performance. Continued education for health professionals is essential in that it provides the necessary tools to cope with ethical problems ${ }^{(4)}$.

Informal conversation between colleagues is usually the first path that professionals seek to solve ethical problems ${ }^{(24)}$. However, as shown in a study included in the review ${ }^{(4)}$, it is not enough to gather professionals and offer time for discussion; these discussions must approach the practice theory and offer practicable solutions. Meetings should preferably occur during work hours and encourage the involvement of all team members ${ }^{(4)}$.

Ethics education can help professionals to define their own values and create the tools and skills they need to cope with ethical problems at work ${ }^{(18)}$. In the review, a study defended initial and permanent ethics education as essential for excellence in care ${ }^{(18)}$.

Evidently, initiatives for continued education and interventions for the permanent ethics education of health professionals will only be effective if the ethical dimension of services is also developed, from planning to the implementation of actions, programmes and institutional polices. Services must undertake to conduct and encourage reflection on ethical problems, as punctual, short-term interventions will have a limited effect (38).

Searches for the review produced a large number of theoretical studies. This is due to the fact that ethics has a vast scope of thought, where researchers can publish studies based on their epistemological and conceptual convergences on this subject. Searches also revealed the small number of empirical studies conducted in PHC, which indicates a knowledge gap on the ethical problems in this area.

Search results for review included publications from indexed journals with a high impact factor and contained reports of academic studies, which, in turn, indicates that universities have been focusing on bioethical issues in PHC, probably due to a perception of the existing gap in the production of knowledge in this area. The fact that publications from the 1990s were found, considering the scarse production in this area, shows that the search was comprehensive and that the inclusion of PHC in the bioethical agenda is recent.
The synthesis of globally relevant research results enables the incorporation of evidence, that is, it allows the transfer of knowledge to nursing practices by defining ethical problems and presenting resources to cope with and solve these problems in the sense of establishing a practice based on citizenship and the emancipation of subjects involved in this process. To make a difference in relation to health care, it is essential to connect knowledge from research to clinical practices.

Actions that target professional work processes fail to tackle ethical issues in PHC, and the health care service and system production processes must be consequently restructured. This includes policies for selecting professionals for PHC, as the lack of preparation, technical competencies and ethics of providers can be a source of problems for colleagues, individually and for the entire health team. The policy of retaining professionals must also be reviewed, as ethical issues cause moral suffering and stress, and may cause turnover among professionals. Management aspects due to scarcity and allocation of human, financial and material resources cause ethical problems and influence their resolution.

Limitations of this study were results that could not be extrapolated to other health care contexts, considering that the analysed studies were of primary health care. Research targeted the assessment of most existing literature, although some limitations in this process were research published in other languages and the diversity of studies that probably exist in other indexing databases that were not included in this study. The integrative literature review is merely one of the many methods that can be employed to analyse ethical problems and another method may have generated different results. Further explorations of ethical problems experienced by nurses using other methods or other contexts, such as the hospital or academic environment, are therefore recommended.

\section{GINAL CONSIDERATIONS}

As ethical problems in PHC commonly occur in daily routine health care practices, which hinders perception of these problems, we concluded that the results of this review may be helpful to nurses who work at this level of health care. These nurses must be prepared and aware of ethical problems in order to recognize and cope with them. Issues related to autonomy, privacy and confidentiality of users are quite present in the ethical problems found in the review. This indicates that the patient-nurse relation- 
ship in PHC should be given special attention to ensure that contact is continuous and present in the homes and families of users.

As a path for confronting this problem, this study emphasizes the importance of maintaining permanent education in ethics to develop practical skills, competency and ethical sensitivity that leads to thought, discussion and the prudent and responsible resolution of ethical problems. Permanent education initiatives for nurses in PHC must be capable of encouraging thought on work processes and the associated moral issues to broaden ethical horizons.

Professionals seem willing to receive this type of education inasmuch as they indicate basic and permanent training as a resource to cope with ethical issues in PHC, valuing formal and informal debates, individual and team thought and time to discuss ethical problems. The deliberation model based on problematization emerges as an instrument that is recognized by nurses as a way of coping with ethical matters. This model can be adopted to guide permanent education initiatives of nurses in PHC, and it is one of the relevant contributions of this review to health care practices.

\section{REFERENCES}

1. Souza MB, Rocha PM, Sá AB, Uchoa SAC. Trabalho em equipe na atenção primária: a experiência de Portugal. Rev Panam Salud Publica. 2013;33(3):190-5.

2. Rodrigues LBB, Silva PCS, Peruhype RC, Palha PF, Popolin MP, Crispim JA, et al. A atenção primária à saúde na coordenação das redes de atenção: uma revisão integrativa. Ciênc Saúde Coletiva. 2014;19(2):343-52.

3. Zoboli ELCP, Fortes PAC. Bioética e atenção básica: um perfil dos problemas éticos vividos por enfermeiros e médicos do Programa Saúde da Família, São Paulo, Brasil. Cad Saude Publica. 2004;20(6):1690-9.

4. Lillemoen L, Pedersen R. Ethical challenges and how to develop ethics support in primary health care. Nurs Ethics. 2012;20(1):96-108.

5. Junges JR, Zóboli ELCP, Schaefer R, Nora CRD, Basso M. Validação da compreensibilidade de um instrumento sobre problemas éticos na atenção primária. Rev Gaúcha Enferm. 2014;35(2):148-56.

6. Basso-Musso L. Nursing and the resolution of ethical dilemmas. Invest Educ Enferm. 2012:30(2):260-8.

7. Zoboli ELCP. Enfermeiros e usuários do programa saúde da família: contribuições da bioética para reorientar esta relação profissional. Acta Paul Enferm. 2007;20(3):316-20.

8. Laabs CA. Primary care nurse practitioners' integrity when faced with moral conflict. Nurs Ethics. 2007;14(6):795-809.

9. Laabs CA. Moral problems and distress among nurse practitioners in primary care. J Am Acad Nurse Pract. 2005;17(2):76-84

10. Silva LT, Zoboli ELCP, Borges ALV. Bioética e atenção básica: um estudo exploratório dos problemas éticos vividos por enfermeiros e médicos no PSF. Cogitare Enferm. 2006;11(2):133-42.

11. Whittemore R, Knafl K. The integrative review: updated methodology. J Adv Nurs. 2005;52(5):546-53.
12. Duncan SM. Ethical challenge in community health nursing. J Adv Nurs. 1992;17(9):1035-41.

13. Zoboli ELCP. Relación clínica y problemas éticos en atención primaria, São Paulo, Brasil | Atención Primaria. 2010;24(8):406-14.

14. Gremmen I. Visiting nurses' situated ethics: beyond "care versus justice". Nurs Ethics. 1999;6(6):515-27.

15. Aroskar MA, Moldow DG, Good CM. Nurses' voices: policy, practice and ethics. Nurs Ethics. 2004;11(3):266-76.

16. Davis S, SchraderV, Belcheir MJ. Influencers of ethical beliefs and the impact on moral distress and conscientious objection. Nurs Ethics. 2012;19(6):738-49.

17. Junges JR, Schaefer R, Della Nora CR, Basso M, Silocchi C, Souza MC, et al. Hermenêutica dos problemas éticos percebidos por profissionais da atenção primária. Rev Bioét. 2012;20(1):97-105.

18. Zoboli E, Soares F. Capacitação em bioética para profissionais da saúde da família do município de Santo André, SP. Rev Esc Enferm USP. 2012;46(15):1248-53.

19. Gallagher E, Alcock D, Diem E, Angus D, Medves J. Ethical dilemmas in home care case management. J Healthc Manag. 2002;47(2):85-96.

20. Oberle K, Tenove $S$. Ethical issues in public health nursing. Nurs Ethics. 2000;7(5):425-38.

21. Lima AC, Morales DA, Zoboli ELCP, Sartório NA. Problemas éticos na atenção básica: a visão de enfermeiros e médicos. Cogitare Enferm. 2009;14(2):294-303.

22. Redman BK, Fry ST. Nurses' ethical conflicts: what is really known about them? Nurs Ethics. 2000;7(4):360-6.

23. Rogers W. Ethical issues in public health: a qualitative study of public health practice in Scotland. J Epidemiol Community Heal. 2004;58(6):446-50.

24. Laabs C. Perceptions of moral integrity: contradictions in need of explanation. Nurs Ethics. 2011;18(3):431-40.

25. Katsuhara Y. What moral requirements cause ethical dilemmas among nurse executives? Jpn I of Nurs Sci. 2005;2(1):57-65.

26. Deshefy-Longhi T, Dixon JK, Olsen D, Grey M. Privacy and confidentiality issues in primary care: views of advanced practice nurses and their patients. Nurs Ethics. 2004;11(4):378-93

27. Aitamaa E, Leino-Kilpi H, Puukka P, Suhonen R. Ethical problems in nursing management: the role of codes of ethics. Nurs Ethics. 2010;17(4):469-82.

28. Ulrich C, Soeken K, Miller N. Predictors of nurse practitioners' autonomy: effects of organizational, ethical, and market characteristics. J Am Acad Nurse Pract. 2003;15(7):319-25

29. Ulrich CM, Soeken KL. A path analytic model of ethical conflict in practice and autonomy in a sample of nurse practitioners. Nurs Ethics. 2005;12(3):305-16.

30. Tonnessen S, Nortvedt P, Forde R. Rationing home-based nursing care: professional ethical implications. Nurs Ethics. 2011;18(3):386-96.

31. Zimmermann M. A bioética na formação do profissional enfermeiro : contribuições para um cuidado mais humanizado [dissertação]. Curitiba: Pontifícia Universidade Católica do Paraná; 2006.

32. Rocha ML. Repensar o ensino de Enfermagem para enfrentar os novos desafios da bioética [dissertação]. Porto: Faculdade de Medicina da Universidade do Porto; 2003.

33. Amado JN. Avaliação da ocorrência de problemas éticos em cuidados de saúde primários [dissertação]. Porto: Universidade Católica Portuguesa; 2010.

34. Silva LT. Construção e validação de um instrumento para avaliação de ocorrência de problemas éticos na atenção básica [dissertação]. São Paulo: Universidade de São Paulo; 2008.

35. Bouças ICOM. Ensino e aprendizagem da bioética em enfermagem perspectiva dos estudantes [dissertação]. Porto: Faculdade de Medicina da Universidade do Porto, 2007. 
36. Fernandes JD. Decisão ética em enfermagem do problema aos fundamentos para 0 agir [tese]. Porto: Universidade Católica Portuguesa; 2010.

37. Melnyk BM, Fineout-Overholt E. Making the case for evidence-based practice. In: Melnyk BM, Fineout-Overholt E. Evidence- based practice in nursing \& healthcare: a guide to best practice. Philadelphia: Lippincot Williams \& Wilkins; 2005. p. 3-24.
38. Jenkins $C L$, Elliott AR, Harris JR. Identifying ethical issues of the department of the army civilian and Army Nurse Corps certified registered nurse anesthetists. Mil Med. 2006;171(8):762-9.

39. Dalmolin GL, Lunardi VL, Lunardi GL, Barlem ELD, Silveira RS. Sofrimento moral e síndrome de Burnout: existem relações entre esses fenômenos nos trabalhadores de enfermagem? Rev Latino-Am Enfermagem. 2014;22(1):35-42.

\section{Author's address:}

Carlise Rigon Dalla Nora

Rua João Pedro Ribeiro, 885, 1D

4000-308, Porto, Portugal

E-mail: carliserdn@gmail.com
Received: 16.07.2014

Approved: 05.12.2014 